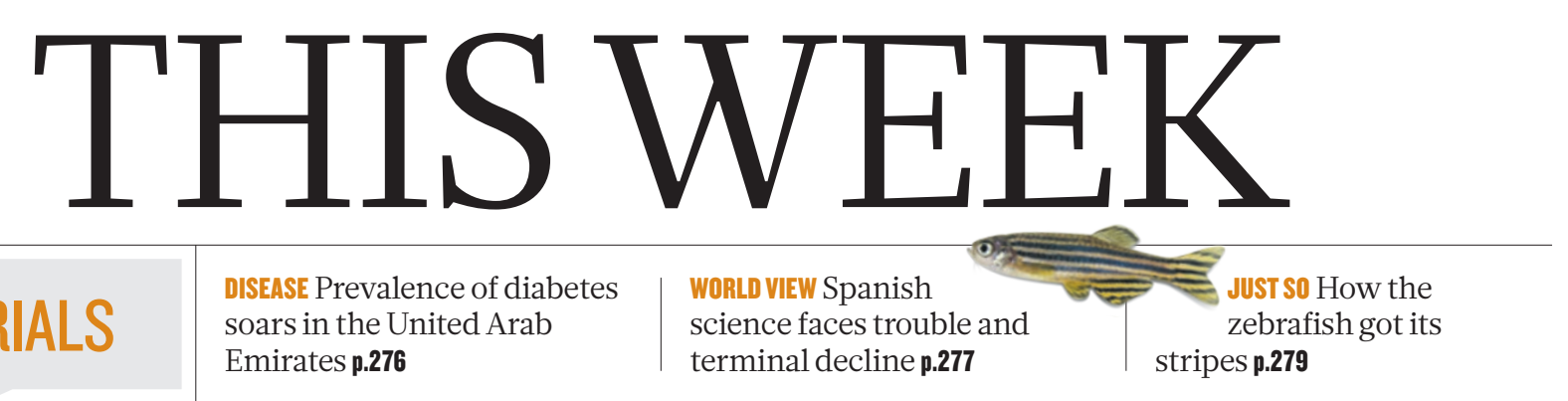

EDITORIALS soars in the United Arab Emirates p.276

terminal decline $\mathbf{p} \mathbf{. 2 7 7}$

\title{
Worldwide weapons
}

\author{
Progress towards a United Nations arms-trade treaty is encouraging, but it won't keep weapons \\ out of the hands of human-rights abusers.
}

S cientists are prominent among those trying to make the world a safer place. Albert Einstein was committed to the international peace effort, and Soviet nuclear physicist Andrei Sakharov and US chemist Linus Pauling are among the researchers who have been awarded the Nobel Peace Prize. The Polish-British nuclear physicist Joseph Rotblat received the peace prize in conjunction with the Pugwash Conferences on Science and World Affairs, the nuclear-disarmament organization that he helped to found (see Nature 481, 438-439; 2012). The attitudes of these researchers chime with the internationalism of the scientific endeavour and the humanitarian goals that often motivate it.

At the same time, science and technology are integral to military development, and defence funding supports a great deal of research, much of it excellent. There need be no contradiction here: nations have a right to self-defence, and armed forces are often deployed for peacekeeping as well as for aggression. But what constitutes responsible use of military might is controversial, and peace-keeping is generally necessary only because aggressors have been supplied with military hardware in the first place.

All of this makes arms control a thorny subject for scientists. When, at a session on human rights at a physics conference several years ago, Nature asked whether the link between the arms trade and humanrights abuses might raise ethical concerns about research on offensive weaponry, the panellists shuffled in their seats and became tongue-tied.

There is no easy way to demarcate the ethical boundaries of defence research. But scientists should welcome progress towards a binding United Nations Arms Trade Treaty (ATT), for which a preparatory meeting in New York this week presages final negotiations in July.

The treaty aims to align the conditions and standards for arms exports from all signatory countries. The UK government's Foreign and Commonwealth Office (FCO), which supports the ATT, says that inconsistencies and loopholes in current regional and national control systems for the arms trade hinder sustainable development, undermine stability and democracy, and impede progress towards the UN's Millennium Development Goals.

Some nations will attempt to have the treaty watered down. That the sole vote against the principle at the UN General Assembly in October 2009 was from Zimbabwe speaks volumes about probable reasons for opposition. But let us not overlook the fact that in a vote a year earlier, Zimbabwe was joined by one other dissenter: the United States, then led by President George W. Bush. Would any of the current leading US Republican candidates for president be better disposed towards an ATT?

Even if it does go ahead, a treaty will not necessarily change the arms trade much. Most of the military technology used for human-rights abuses in recent decades has been obtained legally. Sales from Britain, for example, helped Libya's former leaders to suppress 'rebels' in 2011 and enabled Zimbabwe to launch assaults in the Democratic Republic of Congo in the 1990s.

\section{DNATURE.COM}

For more on science and the military: nature.com/military
The UK government admits that the ATT will probably not reduce arms sales. It says that the criteria for exports "would be based on existing obligations and commitments to prevent human rights abuse" - which have not been notably effective. According to the FCO, the treaty aims "to prevent weapons reaching terrorists, insurgents and human rights abusers". But as demonstrated "The Arms in Libya, one person's insurgents are another's Trade Treaty democratizers, and today's legitimate rulers can couldsimply be tomorrow's human-rights abusers.

legitimize

business as usual."

The FCO says that the treaty "will be good for business, both manufacturing and export sales". Indeed, arms manufacturers support it as a way of levelling the market playing field. The ATT could simply legitimize business as usual by clearly demarcating it from the black market, and it will not cover peripheral military hardware such as surveillance and information technology. Some have argued that the treaty will be a distraction from the problem of keeping arms from human-rights violators (D. B. Kopel et al. Penn State Law Rev. 114, 101-163; 2010).

So although there are good reasons to call for a strong ATT, it is no panacea. The real need is to establish what a responsible arms trade would look like, if this isn't an oxymoron. Some hard research is required on how existing, 'above-board' arms sales have affected governance, political stability and socio-economic conditions worldwide. This is challenging and contentious, but several starts have been made, both in the UN and nationally (see, for example, www.unidir.org and www.prio.no/nisat). We need more.

\section{Tough choices}

\section{Scientists must find ways to make more efficient use of funds - or politicians may do it for them.}

$\mathrm{S}$ cientists in the United States can find plenty of good news as they page through President Barack Obama's 2013 budget proposal. Despite substantial cuts elsewhere - and fierce pressure from Republicans to cut more - Obama called for healthy overall increases in both fundamental research and science education (see page 283).

But the good news, of course, is tempered by reality. Obama's budget document is one long struggle to balance two contradictory goals: to stimulate the lagging US economy and to curb the annual budget deficit, which is more than US\$1 trillion. Science and science education are widely viewed as helping with the first, and will doubtless continue to be seen as such no matter who wins November's presidential election. 